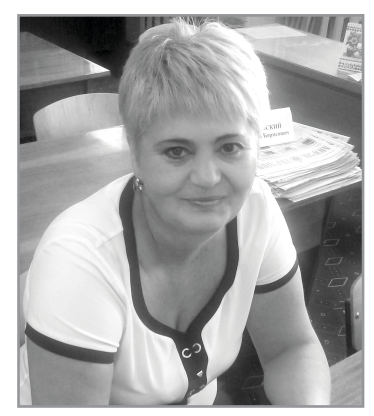

\author{
Olena Kostyria* \\ $\mathrm{PhD}$ in Law, Docent, \\ the member of the Nautical Institute of the \\ Great Britain, MNI \\ (London, United Kingdom) \\ https:// orcid.org/0000-0001-9300-8957
}

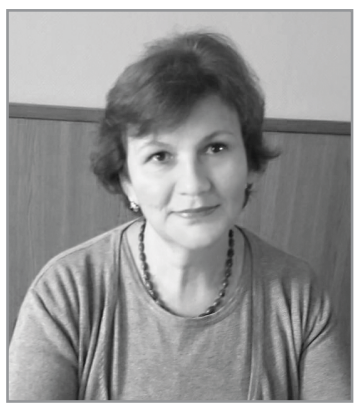

\author{
Alla Ivanova** \\ $\mathrm{PhD}$ in Law, Docent, \\ the expert in the field of law, \\ Institute of state and law of \\ V. M. Koretsky National Academy of Sciences \\ of Ukraine \\ (Kyiv, Ukraine) \\ https://orcid.org/0000-0002-1953-7372
}

*Olena Kostyria, $\mathrm{PhD}$ in Law, Docent, the member of the Nautical Institute of the Great Britain, MNI (202 Lambeth Road, London SE1 7LQ, United Kingdom).

**Alla Ivanova, $\mathrm{PhD}$ in Law, Docent, the expert in the field of law, Institute of state and law of V. M. Koretsky National Academy of Sciences of Ukraine (4, Trokhsviatytelska St., Kyiv, Ukraine).

\title{
INTERNATIONAL LEGAL PROTECTION OF THE MARINE ENVIRONMENT FROM POLLUTION FROM SHIPS ON THE EXAMPLE OF THE BLACK SEA
}

\section{МІЖНАРОДНО-ПРАВОВИЙ ЗАХИСТ МОРСЬКОГО СЕРЕДОВИЩА ВІД ЗАБРУДНЕННЯ З СУДЕН НА ПРИКЛАДІ ЧОРНОГО МОРЯ}




\section{ABSTRACT}

The article is devoted to the research of the protection features of the Black Sea from pollution as a special area of the sea. There are determined pollution categories during the operation of ships (during the implementation of maritime activities on the seabed; caused by port activities, shipbuilding and ship's repairing activities; the ingress of alien species or genetically modified organisms into the marine environment; the release of garbage, food, household and operational wastes into the sea; as a result of emergency circumstances - during accidents; and, pollution resulting from the burial of ships at sea). The international legal framework for the protection of the Black Sea marine environment from pollution during the operation of ships was analyzed. The universal and regional levels of legal regulation of the prevention of marine pollution from ships during their operation are highlighted. Particular attention is paid to the status of the Black Sea as a special area and a particularly vulnerable sea area. The Black Sea was defined as a "special area" of the sea, which is considered so vulnerable to oil pollution that discharges within it were completely prohibited with a few and clearly defined exceptions. To do this, we should refer to the provisions of the 1982 UN Convention on the Law of the Sea, which shares the powers of states in the protection of the marine environment from pollution from ships to the adoption of laws and regulations aimed at protecting the marine environment from pollution from ships, and regarding the enforcement of national laws and regulations, as well as international norms and standards for the prevention of marine pollution from ships. The scope of these powers of states is differentiated depending on the rules for which the marine zone is established, and also on the basis of who takes measures to ensure compliance with the rules and regulations. It is emphasized that in their inland waters and the waters of ports, states have full sovereignty and can establish special requirements related to the reduction, control and prevention of marine pollution, which foreign vessels must satisfy in order to enter and stay in these waters. It is noted that in order to increase the effectiveness of all measures to protect the marine environment from pollution from ships, it is necessary to clearly define the binding standards, that is, those that are international, the observance of which states under whose flag the vessels fly, as well as coastal countries, may require vessels located in their territorial waters or exclusive economic zone.

The key words: international legal regulation, pollution from ships, special area, especially vulnerable marine area, protection of the marine environment of the Black Sea.

\section{Introduction}

The protection of the oceans from pollution, as an integral part of the overall problem of conservation of the planet's nature, remains an urgent task for humanity.

Scientific and technological progress in shipbuilding, the use of new technologies and materials in shipbuilding, the transportation of various 
cargoes, including dangerous ones, as well as non-compliance with the requirements for safe disposal and discharge of pollutants, can lead to deterioration of marine ecology, accidents and disasters at sea can cause environmental disasters.

According to an assessment by the Joint Expert Group on the Scientific Aspects of Marine Pollution, the level of pollution from ships takes a large part of the total pollution coming into the waters of the seas, including the Black Sea. There are about 61,000 merchant ships moving in it's waters every year. A chemical analysis of the Black Sea water shows the presence of 124 contaminants, including pesticides, mercury, antibiotics, etc. (Meeresumweltschutz fur Nord-und Ostsee, p. 105). According to environmentalists, one of the main reasons for this dangerous situation is geographical location. The Black Sea is one of marine ecosystems in Europe the most isolated and most sensitive to the impacts of human activity. It's surface area is comparable to that of the Baltic or the North Sea, and it's huge catchment area covers almost a third of Europe and includes most of the territory of seventeen countries.

\section{Methodology}

The purpose of this article is to identify scientific developments, domestic and foreign experience, the objectives and trends of international legal support in the field of marine environment protection from pollution by ships such as the Black Sea on the basis of international law and applicable law. To achieve this goal, a system of general scientific and specific methods for the study of legal phenomena and processes was applied. Methodological basis of the article was the methods of analysis and synthesis, historical method and method of system-structural analysis. Theoretical basis of the article was the scientific researches and the norms of the international law, devoted to the improvement of the ways of the prevention of pollution of the marine environment from the ships, which are performed in three main directions: the development of the methodology of scientific researches for the construction of new ship structures and mechanisms and the improvement of the existing ones; creation of theoretical bases for the prevention of pollution of the marine environment and the atmosphere, and practical implementation of effective methods and methods of operation of ships. Thus, in the elaboration of the selected problems, the scientific developments of Gureev V.G., Ezhova T.G., Efentyev V.P. and others were used. 


\section{Scientific research on the prevention of marine pollution from ships}

Along with the tasks of technical improvement of ships and their equipment there are the tasks of optimal use of existing regulatory and technical means, which allows them to improve the experience of providing prevention of pollution of the marine environment and the atmosphere during the operation of ships and to seek ways to modernize management tools aimed at implementing the new principles, conversion of schematic diagrams and techniques of use.

Paragraph 4 of Art. 1 of The United Nations Convention on the Law of the Sea 1982 states that "... pollution of the marine environment means the introduction into the marine environment of a person, directly or indirectly, of bioenergy, including estuaries, which adverse or may adverse effects such as damage to living resources and life in the sea, danger to human health, obstacles to activities at sea, including fishing and other legitimate uses of the sea, reducing the quality of seawater used and deteriorating recreational conditions".

Considering the use of the oceans for scientific purposes, the carriage of passengers and cargo, fisheries and pollution-causing sources, it is possible to identify such categories of pollution from the operation of ships as:

- Pollution caused by seafloor activities (in particular, exploration and development of natural resources of the seabed and subsoil, such as oil, gas and other minerals in the high seas). This pollution is connected with observance of rules of safety of this type of works at sea, regulation of design, construction, equipment, operation of artificial installations and devices, as well as timely implementation of measures for accident prevention and elimination of emergency situations. Thus, according to part 13 of section, The Third National Program for the Protection and Reproduction of the Environment of the Azov and Black Seas it is defined that: "Dredging and dredging works in marine waters leads to degradation of bottom biocenoses and pollution of the marine environment with dependent and toxic substances";

- Pollution caused by merchant shipping, port activities; shipbuilding and ship's repairing activities. The use of petroleum products like fuel and lubricants is accompanied by losses in the form of leaks from fuel and oil systems, small spills caused by repairing works, accidental spills while lubricants replacing, cleaning filters. The main problem of contamination with oil or petroleum-containing substances is the non- 
compliance with the rules and measures for the safety of the maritime vehicle management and offshore operations (Guriev, Efent'ev, Vihrov, 2004, p. 84). Ukraine signed and ratified international legal instruments aimed at comprehensive prevention of ship-source pollution, such as: The Convention on International Rules for the Prevention of Collisions at Sea, 1972, The International Convention for the Prevention of Pollution from Ships, 1973/78, The International Convention on Standards of Preparation, Certification of fishing vessel personnel and watchkeeping in 1995, Protocol on cooperation in combating marine pollution of the Black Sea with oil and other harmful substances in emergency situations to the Convention its protection of the Black Sea from pollution and others;

- Pollution caused by the introduction into the marine environment of non-native species or genetically modified organisms. The use of seawater for ballasting and washing of cargo vessels causes the most significant pollution of the marine environment in existing methods of operating ships. States of the flag of a ship or a State pursuing scientific activities in the maritime space shall take all measures necessary to prevent contamination by intentional or accidental introduction into their jurisdiction or control of new organisms that are alien or new to any part of the marine environment. According to Art. 196 of the 1982 United Nations Convention on the Law of the Sea, "States shall take all measures necessary to prevent, reduce and maintain under control the pollution of the marine environment by the use of technology under their jurisdiction or control, or the deliberate or accidental introduction of species of organisms, alien or new for any particular part of the marine environment that may cause significant and harmful changes in the marine environment";

- Pollution caused by emissions into the sea of garbage, food, household and operational waste. Offshore waste, due to its diversity, has a negative impact on the marine environment. Disposal of debris from ships in the high seas and "special areas" is governed by the rules of Annex V of the International Convention for the Prevention of Pollution from Ships, $1973 / 78$, and in inland and territorial waters by national rules and the laws of the coastal State. In the Baltic Sea, garbage dumping is established by the Convention on the Baltic Sea Marine Conservation Commission;

- Pollution caused by harmful emissions from ships into the atmosphere. In addition to seawater, the self-propelled vessel also consumes atmospheric air to provide fuel combustion in marine power plants. In this 
case there is a thermal pollution of the atmosphere caused by the emission of flue exhaust and flue gases from marine engines and boilers, as well as pollution in the form of unburnt fuel particles and products of its smoking, which entail various harmful compounds (sulfur oxide, nitrogen carbon, heavy metals). These emissions are scattered in the atmosphere, deposited on the surface of the water and dissolved in it. Annex VI of the International Convention for the Prevention of Pollution from Ships 1973/78, which sets out the "Rules for the prevention of atmospheric pollution from ships" and the "Technical Code for the control of nitrogen oxides from ships engines" aiming at comprehensive prevention of pollution from ships of atmospheric air;

- Emergency pollution caused by accidents. In such cases, pollution causes catastrophic consequences for the fauna, flora and fauna, and also causes significant economic damage to countries off the coast of which pollution has occurred;

- Pollution caused by burial in the marine environment. According to paragraph 1 of Art. 210 of the 1982 United Nations Convention on the Law of the Sea, states adopt laws and regulations for the prevention, reduction and conservation of marine pollution as a result of storage, and Article 3 of the Convention establishes the obligation to have a permit for burial from the competent authorities of the States concerned. It's prohinited to bury within the territorial sea, exclusive economic zone or continental shelf without the express prior approval of the coastal State having the right to authorize, regulate and to supervise such storage after due consideration of the matter with other States where such storage may be adversely affected by their geographical location.

Oil pollution and oil spills are rated as one of the biggest environmental threats to the Black Sea. Intensive shipping risks require the coordination of all emergency management resources at both national and regional levels.

\section{Legal and regulatory support for the prevention of marine pollution}

All international norms aimed at preventing and protecting the marine environment of the Black Sea from pollution from ships can be attributed to universal and regional levels. Universal standards are adopted at the level of the United Nations (hereinafter referred to as the UN) and its specialized agency, the International Maritime Organization (hereinafter referred to as IMO). The regional rules governing the prevention of pollution of the 
Black Sea from ships should be distinguished such as: The Convention for the Protection of the Black Sea against Pollution 1992 and the Protocol for the Protection of the Black Sea Marine Environment from Pollution from Shore Sources; Protocol on cooperation in the fight against pollution of the Black Sea marine environment by oil and other harmful substances in emergency situations; Protocol on the Protection of the Black Sea Marine Environment against Pollution from Discharges, which is an integral part of the Convention. In addition, a Black Sea Recovery and Protection Action Plan acts for the Black Sea.

It should be noted that the peculiarity of regulation of pollution from ships is that the most important here are the universal standards established at the IMO level. This is due to the need for a harmonious combination of several important aspects: on the one hand, the safety of navigation and, on the other, the protection of the marine environment from pollution from ships. As T. Ezhova notes, "it is better to do this at a multilateral international level, where countries can agree and develop uniform rules that will be applied on an equal footing so as not to cause problems for the freedom of navigation" (Ezhova, 2017, p. 80).

One of the first international treaties relating to the issue of marine ecology was the 1954 International Convention for the Prevention of Pollution from the Sea. The main generally recognized set of rules and regulations in the field of marine pollution protection from ships is The International Convention for the Prevention of Pollution from Ships 1973, supplemented by the 1978 Protocol (hereinafter MARPOL 73/78). The Convention contains rules for the prevention of pollution of the sea by oil, harmful substances carried in bulk and in packaging, waste water and debris, as well as rules for the prevention of pollution of the atmosphere when operating ships contained in six annexes to the Convention. Currently, the norms set by MARPOL $73 / 78$ apply to more than $90 \%$ of the world's merchant fleet. Article 2, paragraph 2, of MARPOL 73/78, provides a sufficiently broad definition of what concerns to harmful substances: “... any substance which, if released into the sea, is likely to endanger human health, harm living resources, marine fauna and flora, disrupt the natural attractiveness of the sea as a holiday destination or interfere with other legitimate uses of the sea".

MARPOL 73/78 applies to vessels operating under the flag of a State party to the Convention; and ships that are under the operational management of a participating State, regardless of their flag, except 
for military vessels and ships used for governmental non-commercial purposes. However, paragraph 3 of MARPOL 73/78 states that, even with respect to these exceptions, States parties to the Convention are required to ensure that such vessels comply with its provisions.

In addition to the provisions of the MARPOL 73/78 Convention, which have been developed at a universal level, the following is also applied to the international legal regulation of the protection of the marine environment from pollution:

- International Convention for the Protection of Human Life at Sea 1974 (SOLAS - 74), which contains a number of sections relating to the protection of the environment from pollution and port State control (Chapters VI, VIII, VII, IX);

- International Code for the Management of Safe Operation of Pollution and Prevention of Pollution (ICSB), which aims to ensure an international standard for the management of safe operation of ships and the prevention of pollution, the less the number of accidents and incidents with vessels, the less the likelihood of various harmful substances entering and entering. sea;

- The United Nations Convention on the Law of the Sea, 1982, which obliges the acceding States to take all measures to prevent pollution of the marine environment from any source (from shore, from vehicles, from the atmosphere);

- The International Convention on the Training, Certification of Seafarers and Watchkeeping 1978/95, contains the requirements for the professional training of professionals in the maritime field, including the application of environmental measures, both while at sea and at anchor in port;

- The International Carriage of Goods Convention 1966, which contains requirements for the design and design of ships, which are also important factors in preventing pollution of the sea when operating ships;

- International rules for the prevention of collisions of ships at sea in 1972, aimed at preventing ship crashes as a result of collisions and, therefore, serve the purpose of reducing the risk of marine pollution;

- International Convention on Civil Liability for Oil Pollution Damage 1969 , as subsequently amended and applied exclusively to damage caused by pollution in the territory of a Contracting State (including its territorial sea and the EEZ), and to preventive measures taken to prevent or reduce such damage; 
- Convention on the Establishment of the International Oil Pollution Compensation Fund 1971, as amended 2000, the purpose of which is to establish and operate a fund to provide compensation for marine pollution damage to the extent that the protection afforded by the International Convention on civil liability for the damage caused by oil pollution in 1969 is insufficient.

To protect the marine environment from pollution, provisions and international codes, such as: the International Code for the Construction and Equipment of Ships Carrying Hazardous Chemical Cargoes in Bulk; International Code for the Construction and Equipment of Ships Carrying Liquefied Gases in Bulk; International Code for the Carriage of Dangerous Goods by Sea.

\section{Improvement of the Black Sea pollution prevention measures during the operation of ships}

Considering the protection of the Black Sea marine environment from pollution from ships, first of all it is necessary to determine the extent of coastal powers' authority to take measures designed to ensure an adequate level of marine environment protection. To this end, reference should be made to the provisions of The United Nations Convention on the Law of the Sea 1982, which divides the powers of States in the field of marine pollution protection from ships into laws and regulations designed to protect the marine environment from pollution from ships, and that they concern the enforcement of national laws and regulations, as well as international norms and standards for the prevention of marine pollution from ships. The scope of these powers is differentiated by States depending on which maritime zone is subject to safeguard rules and depending on the measures taken to enforce the envisaged rules and regulations.

Paragraph 1 of Art. 211 of The United Nations Convention on the Law of the Sea 1982 establishes that "States, acting through a competent international organization, establish international norms and standards for the prevention, reduction and preservation of marine pollution from ships and promote systems of minimization the threat of accidents that could cause pollution of the marine environment, including the coast". In addition, paragraph 2 of Art. Article 211 of the Convention establishes the obligation of States to apply to ships operating under their flag national laws and regulations for the prevention, reduction and control of marine 
pollution from ships. These national laws must be at least as effective as generally accepted international norms and standards.

Within their inland waters and ports, States have full sovereignty and may impose specific requirements related to the reduction, control and prevention of marine pollution that foreign vessels must satisfy in order to enter and stay in these waters. According to paragraph 3 of Art. 211 of The United Nations Convention on the Law of the Sea 1982. Each State may request from a ship in its territorial sea and having the flag of another State, information about where it is headed, as well as compliance with established port access requirements.

In accordance with the provisions of paragraph 4 of Art. 211 of The United Nations Convention on the Law of the Sea 1982, to foreign vessels within the territorial sea and exercising the right of peaceful passage, the coastal State may take measures to protect the marine environment from pollution from ships.

In an exclusive economic zone, a coastal State may adopt laws and regulations designed to reduce, control and prevent marine pollution from ships, but only within the framework of international standards and regulations. However, there may be specific areas of the EEZ that require special mandatory measures to prevent marine pollution from ships. The separation of such areas is due to technical reasons related to oceanographic and economic conditions, as well as to the use of the area or the protection of its resources and the particular nature of the movement of ships. In addition to The Convention on the Law of the Sea 1982, the term "special area" is also found in the annexes of the MARPOL 73/78 Convention, but they have different meanings.

According to The United Nations Convention on the Law of the Sea 1982, a "special area" is a part or a specific area within the exclusive economic zone of a State in which that State adopts additional protective measures. MARPOL 73/78 (Annex I, Rule 10 (1); Annex II, Rule 1 (7); Annex V, Rule (5)) states that a "special area" is an area of the sea where for recognized reasons relating to its oceanographic and environmental conditions and the specifics of shipping, it is necessary to adopt specific mandatory methods of preventing pollution of the marine environment. In this definition there are no restrictions on sea space, that is, a "special area" may include maritime spaces with different international legal regimes, including these may be whole seas, and not just certain areas of the exclusive economic zone. 
In 1973, according to Annex I to MARPOL 73/78, which lays down rules for the prevention of marine oil pollution from ships, the Black Sea was designated a "special area" of the sea, considered so vulnerable to oil pollution that discharges within it were completely prohibited with small and well-defined exceptions. This status of the Black Sea has been active since 02.10.1983. In addition, in 1973, pursuant to Annex II of MARPOL $73 / 78$, the Black Sea was also recognized as a "special area" in which the discharge of wastes containing toxic substances was not allowed in any case under Annex V of the MARPOL 73/78 Black Convention. The sea was also recognized as a "special area" in which all appropriate measures should be taken to prevent pollution of the marine environment by debris from ships, the said provision came into force on 01.10.1989.

The Convention on the Protection of the Black Sea against Pollution 1992 and its Protocol on Cooperation in the Pollution of the Black Sea Marine Pollution by Oil and Other Hazardous Substances in Emergency Situations provided the legislative institutional framework for regional cooperation in the elimination of marine pollution. The Strategic Plan for the Reproduction and Protection of the Black Sea, signed in 1996 by the Ministers of the Black Sea State, has become a comprehensive document setting out priority actions for the reproduction and protection of the Black Sea and setting targets for reducing pollution from landbased sources, direct marine pollution and mitigation of river runoff; the restoration of the Black Sea ecosystem and the balanced development of the Black Sea states, as well as set clear goals and timelines for the Regional Action Plan for the Elimination of Marine Pollution by Oil and Other Hazardous Substances in Emergencies.

In 2001, the Parliament of Ukraine approved the National Program for the Protection and Reproduction of the Environment of the Azov and Black Seas. This document sets out goals, objectives, priorities, a timetable for action, identifies responsible state authorities and stakeholders, budgets and sources of funding for the protection and restoration of the Azov and Black seas. The program has been developed in accordance with national rules and standards and is justified by the National Black Sea Action Plan. According to the Law, the Ministry of Environmental Protection of Ukraine oversees and coordinates activities aimed at achieving the objectives of the said Program. The program has a cross-sectoral structure and includes pollution reduction and control issues, integrated coastal zone management, human health, biodiversity 
and landscapes protection, sustainable use of marine resources, environmental monitoring, emergency response and more.

\section{Conclusions}

By international standards, the Black Sea has been defined as a "special area" of the sea, which is considered so vulnerable to pollution by oil, harmful substances and debris that discharges within it have been completely prohibited with small and clearly defined exceptions. To do so, we should refer to the provisions of the 1982 United Nations Convention on the Law of the Sea, which divides the powers of States in the field of marine pollution protection from ships into: related to the adoption of laws and regulations aimed at protecting the marine environment from pollution from ships, concerning the enforcement of national laws and regulations, as well as international norms and standards for the prevention of marine pollution from ships.

The extent of these powers of States is differentiated depending on which maritime zone is established, as well as depending on the measures taken to enforce the rules and regulations.

Thus, defining the legal support for the prevention of marine pollution from ships, it should be noted that in order to improve the effectiveness of all measures to protect the marine environment from pollution from ships, it is necessary to clearly define the mandatory standards, i.e. those related to international standards and the standards to which States under whose flag vessels are registered, as well as coastal countries, may require vessels located in and in their territorial waters or in exclusive economic zones.

\section{REFERENCES}

Convention on the Law of the Sea, 1982 (The United Nations). The official website of UN. Retrieved from: http://www.un.org/depts/los/convention_agreements/texts/unclos/ unclos_e.pdf (2020, February, 15).

Ezhova, T.G. (2017). Mezhdunarodno-pravovaja zashhita morskoj sredy ot zagrjaznenija s sudov na primere Baltijskogo morja [International legal protection of the marine environment from pollution from ships on the example of the Baltic Sea]. Vestnik Baltijskogo federal'nogo universiteta im. Kanta. [Bulletin of the Kant's Baltic Federal University], 9, 79-88. [in Russian].

Gur'ev, V.G, Efent'ev. V.P., Vihrov, B.D. (2004). Predotvrashhenie zagrjaznenija okruzhajushhej sredy s sudov [Prevention of environmental pollution from ships]. Moscow: Mir. [in Russian]. 
International Convention for the Prevention of Pollution from Ships, 1973 (International Maritime Organization). EcoLex. Retrieved from: http://www2.ecolex.org/server2neu.php/ libcat/docs/TRE/Full/En/TRE-000113.txt (2020, February, 15).

Konventsiia pro zakhyst Chornoho moria vid zabrudnennia, 1992 (Ukraina, Turechchyna, Rosiiska Federatsiia, Rumuniia, Hruziia, Bolhariia) [Convention for the protection of the Black Sea against pollution 1992 (Ukraine, Turkey, Russian Federation, Romania, Georgia, Bulgaria)]. Ofitsiinyi sait Verkhovnoi Rady Ukrainy. [The official website of the Verkhovna Rada of Ukraine]. Retrieved from https://zakon.rada.gov.ua/laws/show/995_065 (2020, February, 04). [in Ukrainian].

Meeresumweltschutz fur Nord-und Ostsee: Sondergutachten, December (2018). SRU, Der Rat von Sachverstandigen far Umweltfragen. Baden-Baden. [in German].

Zakon pro zatverdzhennia Zahalnoderzhavnoi prohramy okhorony ta vidtvorennia dovkillia Azovskoho i Chornoho moriv, 2001 (Verkhovna Rada Ukrainy) [Law on Approval of the National Program for the Protection and Reproduction of the Environment of the Azov and Black Seas, 2001 (Verkhovna Rada of Ukraine)]. Ofitsiinyi sait Verkhovnoi Rady Ukrainy. [The official website of the Verkhovna Rada of Ukraine] https:/zakon.rada.gov.ua/laws/ show/2333-14 4 (2020, February, 15). [in Ukrainian].

\section{АНОТАЦІЯ}

Костиря О.В., Іванова А.В. Міжнародно-правовий захист морського середовища від забруднення з суден на прикладі Чорного моря. - Стаття.

Статтю присвячено дослідженню особливостей міжнародно-правового регулювання у сфері захисту Чорного моря від забруднення як особливого району моря. Визначено категорії забруднювачів моря при експлуатації суден (спричинене торговельним судноплавством, спричинене введенням у морське середовище немісцевих видів або генетично змінених організмів, забруднення при здійсненні морегосподарської діяльності на морському дні та портової діяльності; спричинене викидами у море сміття, харчових, побутових та експлуатаційних відходів; спричинене в результаті надзвичайних обставин, зокрема, при аваріях; спричинене похованням у морському середовищі) та проведено їх класифікацію. Проаналізовано міжнародно-правові основи забезпечення захисту морського середовища Чорного моря від забруднення 3 суден. Визначаються універсальний i регіональний рівні правового регулювання попередження забруднення морського середовища 3 суден. Особливої уваги приділяється статусу Чорного моря як “особливого району” і особливо вразливого морського району, яке вважається настільки вразливим до забруднення нафтою, шкідливими речовинами та сміттям, що викиди у його межах були повністю заборонені з невеликими і чітко визначеними виключеннями. Зазначається, що у своїх внутрішніх водах держави мають повний суверенітет і можуть встановлювати особливі вимоги, пов'язані зі скороченням, контролем і запобіганням забрудненню морського середовища, яким повинні задовольняти іноземні судна для можливого заходження та 
знаходження у цих водах. Визначено, що для підвищення ефективності усіх заходів для захисту морського середовища від забруднення з суден, необхідно визначити міжнародні норми, дотримання яких прибережні країни, можуть вимагати від суден, які знаходяться у межах їх територіальних морів та виключних економічних зон.

Ключові слова: міжнародно-правове регулювання, забруднення з суден, особливий район, особливо вразливий морський район, захист морського середовища Чорного моря.

\section{АННОТАЦИЯ}

Костыря Е.В., Иванова А.В. Международно-правовая защитта морской среды от загрязнения с судов на примере Черного моря. - Статья.

Статья посвящена исследованию особенностей защиты Черного моря от загрязнения как особого района моря. Определены категории загрязнителей моря при эксплуатации судов (при осуществлении морехозяйственной деятельности на морском дне и портовой деятельности, при судостроении и судоремонтной деятельности; при попадании в морскую среду чужеродных видов или генетически измененных организмов; при выбросах в море мусора, пищевых, бытовых и эксплуатационных отходов; в результате чрезвычайных обстоятельств, в частности, при авариях; загрязнения в результате захоронения судов в море) и проведена их классификация. Проанализированы международно-правовые основы обеспечения защиты морской среды Черного моря от загрязнения при эксплуатации судов. Выделяются универсальный и региональный уровни правового регулирования предотвращения загрязнения морской среды с судов. Особое внимание уделено статусу Черного моря как “особого района" и особо уязвимого морского района. Черное море было определено “особым районом” моря, который считается настолько уязвимым к загрязнению нефтью, вредными веществами, перевозимым наливом и в упаковке, а также мусором с судов, что выбросы в его пределах были полностью запрещены с небольшими и четко установленными исключениями. Отмечается, что в своих внутренних водах государства имеют полный суверенитет и могут устанавливать особые требования, связанные с сокращением, контролем и предотвращением загрязнения морской среды, которым должны соответствовать иностранные суда для возможного захода и нахождения в этих водах. Отмечено, что для повышения эффективности всех мероприятий по защите морской среды от загрязнения с судов необходимо определить международные нормы, соблюдение которых прибрежные страны могут требовать от судов, находящихся в их территориальных морях или исключительных экономических зонах.

Ключевые слова: международно-правовое регулирование, загрязнение с судов, особый район, особенно уязвимый морской район, защита морской среды Черного моря.

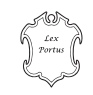

